Tropical Journal of Pharmaceutical Research December 2015; 14 (12): 2201-2206

ISSN: $1596-5996$ (print); 1596-9827 (electronic)

(c) Pharmacotherapy Group, Faculty of Pharmacy, University of Benin, Benin City, 300001 Nigeria.

All rights reserved.

Available online at http://www.tjpr.org

Original Research Article

http://dx.doi.org/10.4314/tjpr.v14i12.7

\title{
Withaferin A Suppresses Anti-apoptotic BCL2, Bcl-xL, XIAP and Survivin Genes in Cervical Carcinoma Cells
}

\author{
Li Ye* and Qian Song \\ Department of Obstetrics and Gynecology, Taizhou Cancer Hospital, Taizhou, Zhejiang 317502, China
}

*For correspondence: Email: yeli34343@gmail.com; Tel: 0086-576-8659004; Fax: 0086-576-86590042

Received: 25 March 2015

Revised accepted: 31 October 2015

\begin{abstract}
Purpose: To investigate the effect of withaferin $A$ on the suppression of the anti-apoptotic genes, BCL2, $B C l-X L, X I A P$ and Survivin), in cervical carcinoma cells.

Methods: Annexin V-FITC/propidium iodide (PI) staining was used for the investigation of cell apoptosis. RNA RNeasy Kits was used to isolate RNA and Omniscript RT to reverse and transcribe the mRNA. Quantitative real-time polymerase chain reaction ( $(P C R$ ) was performed using Taq PCR Master Mix Kit.

Results: Withaferin A (WFA) treatment reduced mRNA and protein levels of antiapoptotic genes in MCF-7 and HeLa cervical carcinoma cells. Suppression of BCL2, BCl-xL, XIAP and Survivin induced a significant anti-proliferative effect. Treatment with WFA at a concentration of $20 \mu \mathrm{M}$, decreased cell viability and induced apoptosis. In MCF-7 cells, knockdown of BCL2, BCl-XL, XIAP and Survivin caused 4-fold enhancement in apoptosis rate and $53 \%$ decrease in cell viability.

Conclusion: WFA significantly leads to knockdown of antiapoptotic genes and is, therefore, a promising treatment strategy for cervical cancer.
\end{abstract}

Keywords: Anti-apoptotic genes, Cervical cancer, Apoptosis, Cell viability, BCL2, Bcl-xL, XIAP and Survivin

Tropical Journal of Pharmaceutical Research is indexed by Science Citation Index (SciSearch), Scopus, International Pharmaceutical Abstract, Chemical Abstracts, Embase, Index Copernicus, EBSCO, African Index Medicus, JournalSeek, Journal Citation Reports/Science Edition, Directory of Open Access Journals (DOAJ), African Journal Online, Bioline International, Open-J-Gate and Pharmacy Abstracts

\section{INTRODUCTION}

Cervical cancer is the most frequently observed cancer in women throughout the world. It is estimated that every year 500,000 new cervical carcinoma cases are detected globally and $80 \%$ of them are from developing countries [1,2]. Currently, surgery, radiation and chemotherapy are used for the treatment of cervical cancer. Intracavitary brachytherapy is a technique used to deliver high radiation doses to tumor site without exposing normal tissues to radiation [3,]. Presently, the combination of external beam radiotherapy and intracavitary brachytherapy is considered to be the standard treatment strategy for cervical cancer. Although high cure rates are reported at the early stage of the disease using definitive radiotherapy, in locally advanced cervical cancer cases the cure rates are poor. The 5-year overall survival of only $66 \%$ are reported at the advanced stages [5]. Thus, the discovery of molecules with roles in the treatment of locally advanced cervical cancer is needed.

Maintenance of homeostasis in normal tissues and selective removal of damaged and infected cells is achieved by the process of apoptosis [6].Tumor cells are bestowed with the ability to escape apoptosis [7]. It is reported that tumor cells express higher concentration of antiapoptotic genes including BCL2, Bcl-xL, XIAP and Survivin which enables them to evade 
apoptosis. Among the antiapoptotic genes, BCL2 and $\mathrm{Bcl}-\mathrm{xL}$ help to escape apoptosis by inhibiting cytochrome release from the mitochondria followed by failure to activate caspases [8]. Caspases on activation induce apoptosis in which proteins essential for cell function and stability are cleaved [9].

Extracts of withaferin $\mathrm{A}$ isolate from Witha niasomnifera, are used in traditional East Indian medicine [10]. Withaferin $A$ is the major compound present in the extract of Witha niasomnifera [11,12]. Withaferin $A$ has antiangiogenic effects $[10,13]$ from micromolar doses and inhibits soft tissue sarcoma growth and local recurrence in xenograft experiments [14]. It exhibits proapoptotic and anti-tumor activitities in breast and prostate cancers [15-17]. It is reported that withaferin $A$ usually exerts its effect through NF-Kb, BCL-2, FOXO3A, Hsp90, phosphorylated STAT3 and annexin II [16,1822]. In the present study, effect of WFA on knockdown of antiapoptotic genes including BCL2, Bcl-xL, XIAP and Survivin human cervical carcinoma cell lines was studied.

\section{EXPERIMENTAL}

\section{Cell lines and cell culture}

The human cervical carcinoma cell lines MCF-7, HeLa and ME-180 were purchased from American Type of Culture Collection (ATCC, Manassas, VA, USA). The cells were cultured under standard conditions at $37{ }^{\circ} \mathrm{C}$ in humidified atmosphere containing $5 \% \mathrm{CO}_{2}$.

\section{Reagents and chemicals}

Withaferin A (WFA) was purchased from Sigma Aldrich (St. Louis, MO, USA) and dissolved in dimethyl sulfoxide (DMSO) to a concentration of $100 \mu \mathrm{M}$ as a stock solution. Rabbit antihuman Caspase- 3 , mouse antihuman $\mathrm{Bcl}-2$, and $\beta$-actin were purchased from Cell Signaling (China).

\section{Cell viability assay}

Cervical carcinoma cells were incubated with various concentrations of WFA at $37^{\circ} \mathrm{C}$ for $72 \mathrm{~h}$. MTT viability assay was performed according to manual protocol (Roche Diagnostics). The absorbance was measured at the wavelength of $595 \mathrm{~nm}$.

\section{Apoptosis analysis}

Annexin V-FITC/propidium iodide (PI) staining (Annexin V-FITC Apoptosis Detection Kit I, BD Biosciences, Heidelberg, Germany) was used to examine the apoptosis in cervical carcinoma cells. After $48 \mathrm{~h}$ of WFA treatment flow, cytometry (FACScan, BD Biosciences) was used to examine the cells. The quadrant analysis of Annexin V-FITC/PI plots was performed to determine the percentage of early (Annexin VFITC positive, PI negative) and late (Annexin VFITC positive, PI positive) apoptotic cells. For this purpose, WinMDI2.8 software was employed.

\section{Reverse transcriptase PCR}

For the isolation of total cell RNA RNeasy Kits (Qiagen) was used. The RNA sample (500 ng) was used for reverse transcription to CDNA using Omniscript RT (Qiagen). The cDNA was then employed for quantitative real-time PCR (qPCR) using Taq PCR Master Mix Kit (Qiagen) according to the manual protocol.

\section{Western blot analysis}

The cells after WFA treatment were lysed in ice cold lysis buffer supplemented with protease inhibitors. The cell lysate was subjected to SDSPAGE separation. Proteins were transferred to polyvinyl idenedi fluoride (PVDF) membrane (GE Healthcare, Freiburg, Germany) and then incubated with the primary antibodies. The antibodies were used against BCL2, Bcl-xL, XIAP and Survivin (Sigma-Aldrich, St. Louis, MO, USA) and anti- $\beta$-actin was used as the loading control (Sigma-Aldrich, St. Louis, MO, USA). The polyclonal anti-rabbit immunoglobulin HRP-linked antibody and polyclonal rabbit anti-mouse immunoglobulin HRP-linked antibody were used as the secondary antibodies. For visualization, we used the Enhanced chemiluminescence Kit (GE Healthcare).

\section{RESULTS}

\section{Antiapoptotic gene expression in MCF-7, HeLa and ME- 180 cervical carcinoma cell lines}

The expression levels of the four antiapoptotic genes in MCF-7, HeLa and ME-180 cervical cancer cells was analyzed by quantitative PCR analysis. In all the tested cervical carcinoma cell lines, BCL2, Bcl-xL, XIAP and Survivin were expressed at higher level (Table 1). Among the three tested cell lines, MCF-7 and HeLa cells expressed all the four genes which are antiapoptotic at significantly higher levels thus, were selected for further studies.

Trop J Pharm Res, December 2015; 14(12): 2202 
Table 1: Expression levels of mRNA in MCF-7, HeLa and ME-180 cervical cancer cell lines

\begin{tabular}{lcccc}
\hline $\begin{array}{l}\text { Cell } \\
\text { line }\end{array}$ & BCL2 & BCl-xL & XIAP & Survivin \\
\hline MCF-7 & 0.411 & 33.6 & 4.38 & 5.76 \\
HeLa & 0.134 & 31.3 & 3.12 & 3.87 \\
ME-180 & 0.132 & 11.2 & 2.64 & 2.59 \\
\hline
\end{tabular}

Effect of WFA on expression of genes involved in anti-apoptosis

Among the range of WFA concentrations from 5 to $50 \mu \mathrm{M}$ used to analyse the effect on antiapoptotic gene inhibition, the effect was significant at $30 \mu \mathrm{M}$ concentration. Although, 20 $\mu \mathrm{M}$ WFA concentrations markedly reduced the mRNA levels by $52-59 \%$ after $24 \mathrm{~h}$ treatment, the inhibition rate was increased to $81-86 \%$ at
$30 \mu \mathrm{M}$ concentration of WFA (Figure 1). Thus, a marked antiapoptotic gene inhibition was observed after WFA treatment in MCF-7 and HeLa cell lines.

\section{Molecular effects of WFA on inhibition of genes involved in antiapoptosis}

WFA at $30 \mu \mathrm{M}$ concentration significantly inhibited the mRNA expression levels of antiapoptotic genes in the cervical carcinoma cell lines after $48 \mathrm{~h}$ treatment (Figure 2). BCL2, Bcl$\mathrm{xL}, \quad \mathrm{XIAP}$ and Survivin were decreased respectively by 323942 and $36 \%$ in MCF-7 cells. The results from western blot analysis showed protein reduction after $48 \mathrm{~h}$ of WFA treatment in both MCF-7 and HeLa cervical cancer cell lines (Figure 3).
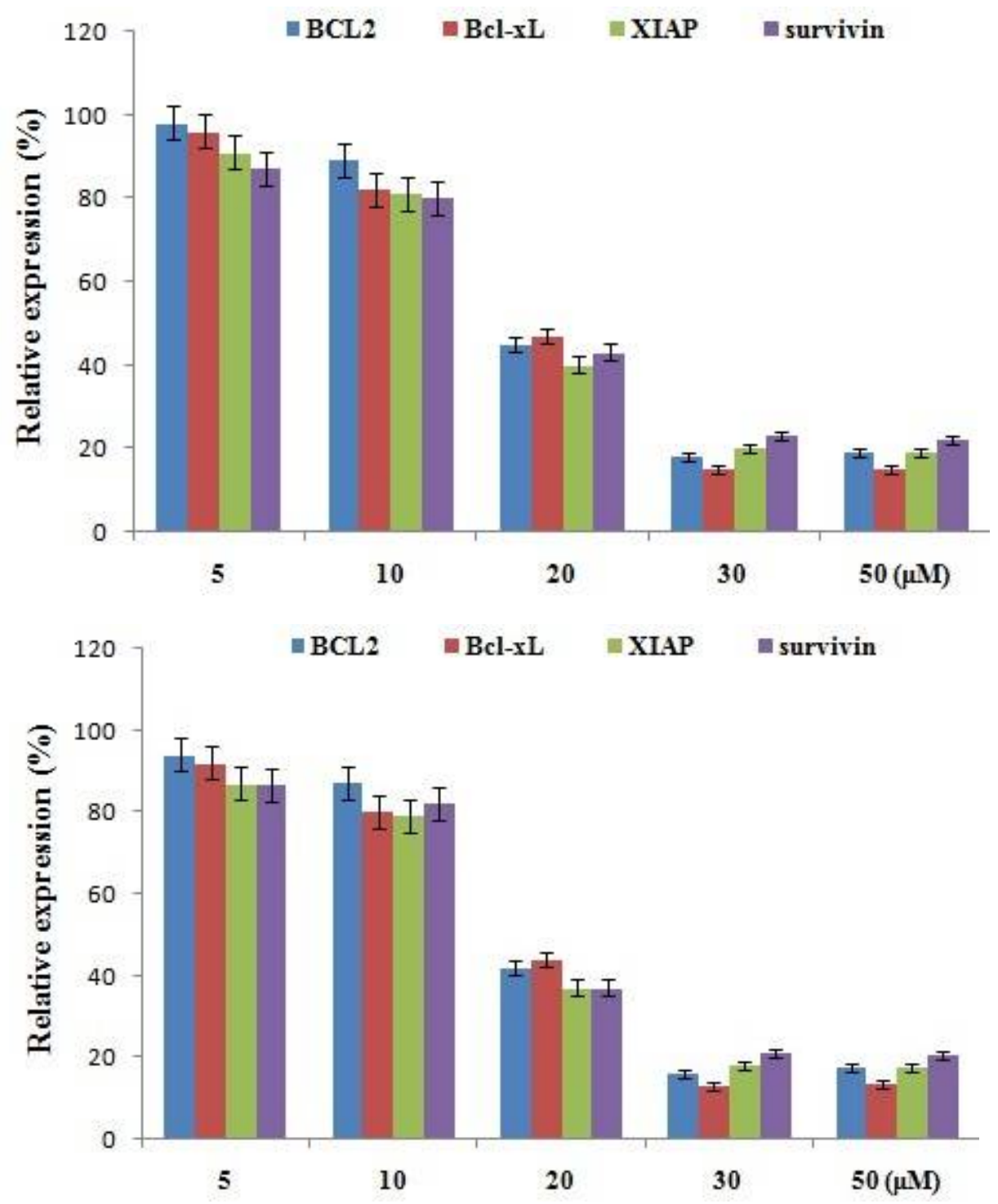

Figure 1: Decrease in the level of BCL2, Bcl-xL, XIAP and Survivin mRNA on treatment with WFA for $24 \mathrm{~h}$ in MCF-7 (upper figure) and HeLa (lower figure) cervical cell lines 


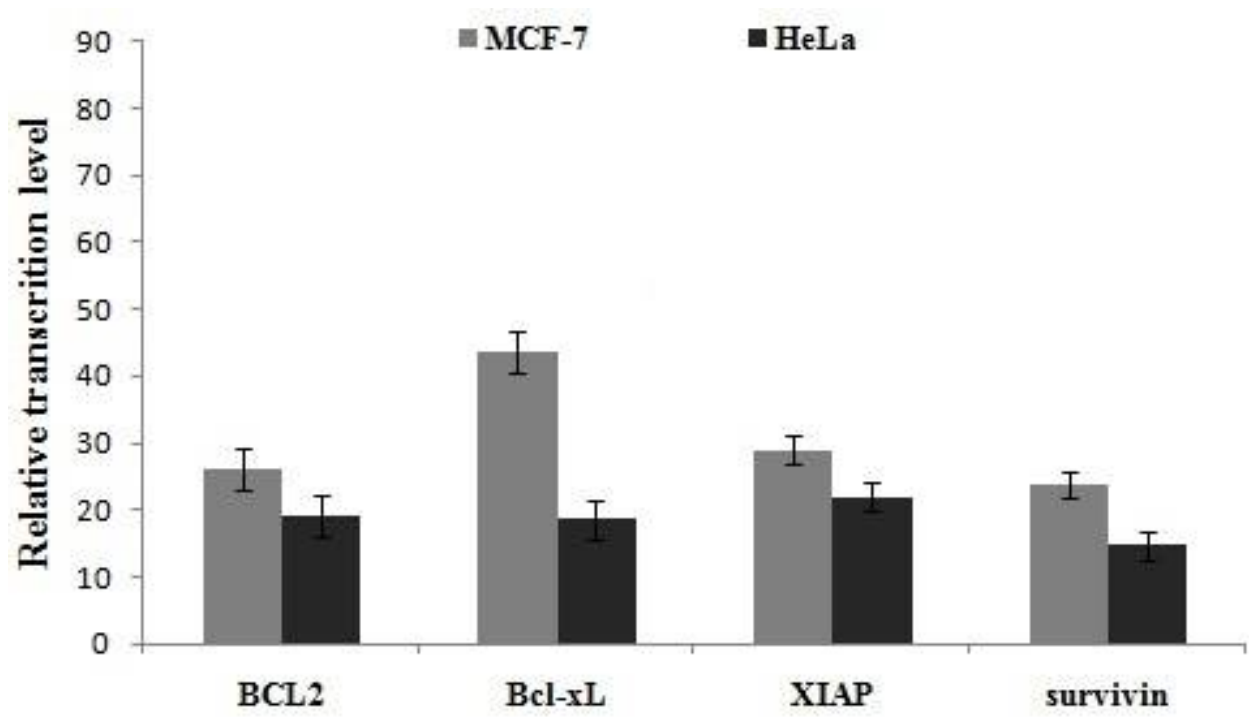

Figure 2: Relative mRNA expression levels of MCF-7 and HeLa cervical carcinoma cells $48 \mathrm{~h}$ after treatment with $30 \mu \mathrm{M}$ WFA. The data presented is the average of three independent experiments

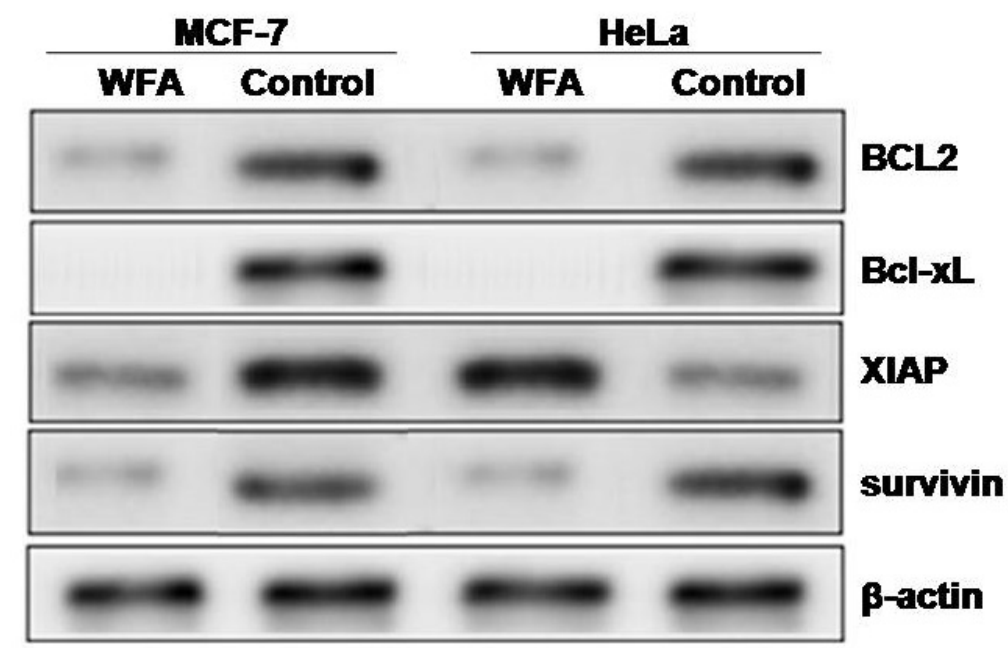

Figure 3: Western blot used to detect BCL2, Bcl-xL, XIAP and Survivin protein in MCF-7 and HeLa cervical carcinoma cells after $48 \mathrm{~h}$ of WFA treatment

\section{Cellular effects of WFA treatment}

The WFA-mediated inhibition of anti-apoptotic genes led to a significant decrease in cervical cancer cell viability (Figure4). The cervical carcinoma cell viability was decreased by 39 and $46 \%$ in MCF-7 and HeLa cells respectively after treatment with WFA for $96 \mathrm{~h}$. The rate of cell apoptosis was also significantly increased on treatment with WFA. In MCF-7cells, there was a 4 -fold increase in the rate of apoptosis (Figure 5). In HeLa cells apoptosis was increased by 3.5 fold (Figure 5). However, no changes were observed in the cell cycle distribution in MCF-7 and HeLa cells on treatment with WFA.

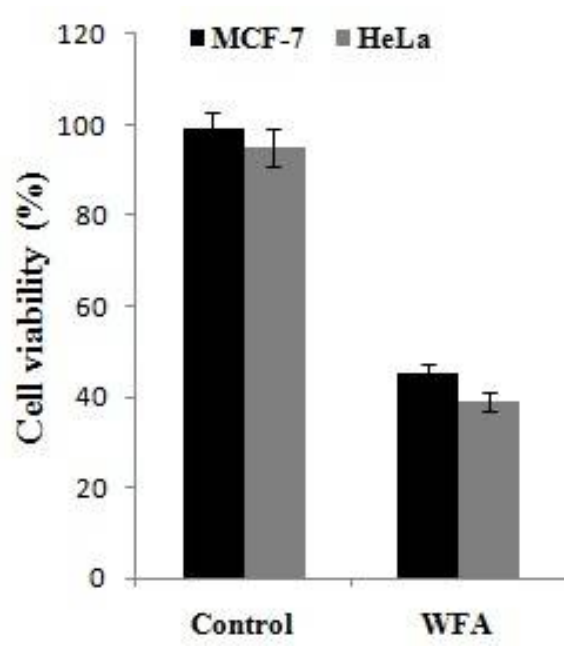

Figure 4: Viability of MCF-7 and HeLa cervical carcinoma cells $96 \mathrm{~h}$ after WFA treatment 


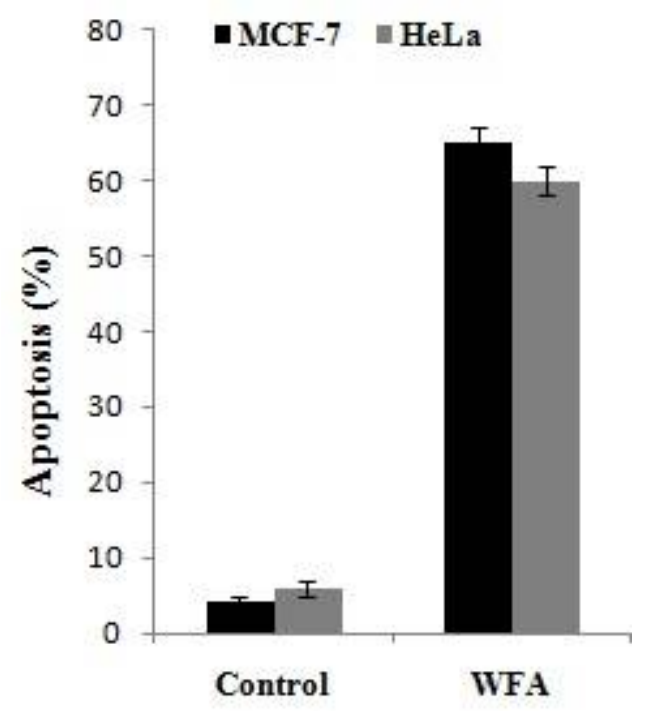

Figure 5: Percentage of early and late apoptotic cells $48 \mathrm{~h}$ after WFA treatment of MCF-7 and HeLa cells. Values represented are the mean of three independent experiments

\section{DISCUSSION}

In tumor tissues the expression of various antiapoptotic genes is found to be markedly higher and plays an important role in inhibiting the induction of apoptosis [23-25]. Thus, antiapoptotic gene inhibition can be a potent strategy for antitumor therapy. It is believed that the inhibition of one antiapoptotic gene can be compensated by the expression of other genes, therefore, inhibition of all the major antiapoptotic genes can have the greatest effect. In the present study, treatment of MCF-7 and HeLa cervical carcinoma cells with $30 \mu \mathrm{M}$ of WFA resulted in the suppression of mRNA corresponding to antiapoptotic gene. WFA significantly inhibited the mRNA and protein levels of anti-apoptotic genes and exhibited strong anti-proliferative effects on MCF-7 and HeLa cervical carcinoma cells. In MCF-7 and HeLa cervical carcinoma cells the proliferation was reduced by 39 and $46 \%$, respectively following WFA treatment for $96 \mathrm{~h}$. Tumor cells are bestowed with the ability to avoid the process of apoptosis [7]. It is reported that the tumor cells express higher level of BCL2, Bcl-xL, XIAP and Survivin antiapoptotic genes which enables them to evade apoptosis. The rate of cell apoptosis was also significantly increased on treatment with WFA. In MCF-7 cells, there was a 4-fold increase in the rate of apoptosis. In case of the HeLa cells the proportion of apoptotic cells was enhanced by 3.5 fold on treatment with WFA. However, in both MCF-7 and HeLa cells WFA treatment could not induce any alteration in the progression of cell cycle. Thus, the current study demonstrates that WFA induces suppression of antiapoptotic gene expression which can be a vital importance for the treatment of cervical cancer.

\section{CONCLUSION}

Thus withaferin A significantly inhibits cervical cancer via knockdown of antiapoptotic genes and is thus a potential therapeutic agent for cervical cancer.

\section{REFERENCES}

1. Ferlay J, Shin HR, Bray F, Forman D, Mathers $C$, Parkin $D M$. Estimates of worldwide burden of cancer in 2008: GLOBOCAN 2008. Int J Cancer 2010; 127: 2893-2917.

2. Garland SM, Cuzick J, Domingo EJ. Recommendations for cervical cancer prevention in Asia Pacific. Vaccine 2008; 26: M89-M98.

3. Nakano $T$, Ohno $T$, Ishikawa $H$, Suzuki $Y$, Takahashi $T$. Current advancement in radiation therapy for uterine cervical cancer. J Radiat Res (Tokyo) 2010; 51: 1-8.

4. Takashi Nakano MD, Shingo Kato MD, Tatsuya Ohno $M D$, Hirohiko Tsujii MD, Shinichiro Sato MD, Kenjiro Fukuhisa BS, Tatsuo Arai MD. Long-term results of high-dose rate intracavitary brachytherapy for squamous cell carcinoma of the uterine cervix. Cancer 2005; 103: 92-101.

5. Cochrane Gynaecological Cancer Group: Reducing uncertainties about the effects of chemoradiotherapy for cervical cancer: individual patient data metaanalysis. Cochrane Database Systematic Rev CD008285, 2010.

6. Burz C, Berindan-Neagoe I, Balacescu O, Irimie A. Apoptosis in cancer: key molecular signaling pathways and therapy targets. ActaOncol2009; 48: 811-821.

7. Hanahan $D$, Weinberg RA. Hallmarks of cancer: the next generation. Cell 2011; 144: 646-674.

8. Brunelle JK, Letai A. Control of mitochondrial apoptosis by the Bcl-2 family. J Cell Sci 2009; 122: 437-441.

9. Taylor RC, Cullen SP, Martin SJ. Apoptosis: controlled demolition at the cellular level. Nat Rev Mol Cell Biol 2008; 9: 231-241.

10. Mohan R, Hammers HJ, Bargagna-Mohan P, Zhan XH, Herbstritt CJ, Ruiz A, Zhang L, Hanson AD, Conner $B P$, Rougas J, Pribluda VS. Withaferin A is a potent inhibitor of angiogenesis. Angiogenesis 2004; 7: 115122.

11. Misra L, Mishra P, Pandey A, Sangwan RS, Sangwan NS, Tuli $R$. Withanolides from Witha niasomnifera roots. Phytochem 2008; 69: 1000-1004.

12. Chaurasiya ND, Uniyal GC, Lal P, Misra L, Sangwan NS, Tuli R, Sangwan RS. Analysis of withanolides in root and leaf of Witha niasomnifera by HPLC with 
photodiode array and evaporative light scattering detection. Phytochem Anal 2008; 19: 148-154.

13. Bargagna-Mohan P, Hamza A, Kim YE, Khuan Abby Ho $Y$, Mor-Vaknin N, Wendschlag N, Liu J, Evans RM, Markovitz DM, Zhan CG, Kim KB, Mohan R. The tumor inhibitor and antiangiogenic agent withaferin $A$ targets the intermediate filament protein vimentin. ChemBiol 2007; 14: 623-634.

14. Lahat G, Zhu QS, Huang KL, Wang S, Bolshakov S, Liu $J$, Torres K, Langley RR, Lazar AJ, Hung MC, Lev D. Vimentin is a novel anti-cancer therapeutic target; insights from in vitro and in vivo mice xenograft studies. PLoS One 2010; 5: e10105.

15. Shohat B, Gitter $S$, Abraham A, Lavie D. Antitumor activity of withaferin $A$ (NSC-101088). Cancer Chemother Rep 1967; 51: 271-276.

16. Stan SD, Hahm ER, Warin R, Singh SV. Withaferin A causes FOXOЗa- and Bimdependent apoptosis and inhibits growth of human breast cancer cells in vivo. Cancer Res 2008; 68: 7661-7669.

17. Srinivasan S, Ranga RS, Burikhanov R, Han SS, Chendil D. Par-4-dependent apoptosis by the dietary compound withaferin $A$ in prostate cancer cells. Cancer Res 2007; 67: 246-253.

18. Falsey RR, Marron MT, Gunaherath GM, Shirahatti $N$, Mahadevan D, Gunatilaka AA, Whitesell L. Actin microfilament aggregation induced by withaferin $A$ is mediated by annexin II. Nat Chem Biol 2006; 2:3338.
19. Singh D, Aggarwal A, Maurya $R$, Naik S. Witha niasomnifera inhibits NF-kappaB and AP-1 transcription factors in human peripheral blood and synovial fluid mononuclear cells. Phytother Res 2007; 21: 905-913.

20. Koduru S, Kumar R, Srinivasan S, Evers MB, Damodaran C. Notch-1 inhibition by Withaferin-A: a therapeutic target against colon carcinogenesis. Mol Cancer Ther 2010; 9: 202-910.

21. Panjamurthy K, Manoharan S, Nirmal MR, Vellaichamy $L$. Protective role of Withaferin-A on immunoexpression of p53 and bcl-2 in 7,12-dimethylbenz(a)anthraceneinduced experimental oral carcinogenesis. Invest New Drugs 2009; 27: 447-452.

22. Yu Y, Hamza A, Zhang T, Gu M, Zou P, Newman B, Li Y, Gunatilaka $A A$, Zhan CG, Sun D. Withaferin $A$ targets heat shock protein 90 in pancreatic cancer cells. Biochem Pharmacol 2010; 79: 542-551.

23. $\mathrm{Li} M$, Song $T$, Yin ZF, Na YQ. XIAP as a prognostic marker of early recurrence of nonmuscular invasive bladder cancer. Chin Med J (Engl) 2007; 120: 469473.

24. Hunter AM, LaCasse EC, Korneluk RG. The inhibitors of apoptosis (IAPs) as cancer targets. Apoptosis 2007; 12: $1543-1568$.

25. Shangary $S$, Johnson DE. Recent advances in the development of anticancer agents targeting cell death inhibitors in the Bcl-2 protein family. Leukemia 2003; 17: 1470-1481. 